\title{
A inmigración irregular en España e Europa: situación e perspectivas
}

\author{
Elena Inglada Galiana* / José Manuel Sastre Centeno / María Cristina de Miguel Bilbao \\ Universidad de Valladolid - Facultad de Ciencias Económicas y Empresariales
}

Recibido: 15 de xullo de 2018 / Aceptado: 22 de xaneiro de 2019

\begin{abstract}
Resumo
A migración é unha particularidade necesaria desde o principio da historia e existe un consenso universal en recoñecer que contribuíu frecuentemente ao progreso das sociedades. Na sociedade española, a inmigración é un dos fenómenos en curso que máis determinou a configuración pasada e futura do país. Este feito tamén aconteceu no ámbito europeo, onde a chegada de estranxeiros foi un fenómeno paulatino e reiterativo en practicamente todos os países. Malia isto, dentro da inmigración, a irregular está asociada a contextos de explotación e vulnerabilidade, onde a invisibilidade destas persoas fronte ao país receptor é un dos maiores atrancos para saír desa situación. A preocupación por este tipo de inmigración é recente, vinculada aos controis fronteirizos e ás políticas migratorias de cada país. A incidencia e a súa extensión en distintos sectores, como o social ou o económico, son múltiples e heteroxéneos. E este é o obxecto de estudo do traballo que se presenta
\end{abstract}

Palabras clave

Exclusión espacial / Integración / Exclusión social / Diferenciación social.

\section{Illegal immigration in Spain and Europe: Situation and outlook}

\begin{abstract}
Migration has been a necessary distinctive feature since the dawn of history and there is a universal consensus in recognizing that it has contributed significantly to the progress of societies. In the Spanish society, immigration is one of the current phenomena that has determined the past and future configuration of the country. This has also happened in Europe, where the arrival of foreigners has been a gradual and repetitive phenomenon in virtually every country. However, illegal immigration is associated with exploitation and vulnerability, where the illegal immigrant becomes invisible in the receiving country, which is one of the greatest obstacles that needs to be overcome. The concern about this type of immigration is recent, and it is associated with the border controls and immigration policies of each country. The incidence and its extension in different sectors, such as social or economic, are multiple and heterogeneous. And this is the object of study of this work.
\end{abstract}

Keywords

Spatial exclusion / Integration / Social exclusion / Functional autonomy.

JEL Codes: F22, J62, K37.

\section{Introdución}

Sen dúbida, a inmigración, polos seus múltiples e relevantes efectos, é un dos temas que máis atención centra na axenda socioeconómica dos actuais gobernos, tanto naqueles países receptores como nos emisores.

Este artigo enfocarase sobre todo na observación da influencia que exerce a intensidade deste fenómeno tanto a nivel social como económico. 0 obxectivo é ofrecer unha perspectiva deste feito social,

* Correspondencia autora: elenaig@eco.uva.es 
concretamente da inmigración ilegal, aquela que se orixina cando os suxeitos que se desprazan non están suxeitos ás leis do país de acollida. Na sección 2 presentamos datos demográficos da inmigración en España e en Europa. A continuación, na sección 3 abórdase a política migratoria e a cooperación internacional. Na sección 4 trátanse as causas e os efectos da inmigración regular e irregular. Na sección 5 abórdase a inmigración ilegal por vía marítima e, finalmente, na sección 6 recóllense as principais conclusións.

\section{Datos demográficos da inmigración en España e Europa}

Os expertos na materia sinalan que a principal causa da inmigración española foi o efecto chamada do mercado laboral durante o período 2000-2008, con heteroxéneos ámbitos beneficiándose do traballo do inmigrante escasamente remunerado (González-Ferrer, 2013, 2014; Villanueva, 2013). Nestes anos, a poboación en España, en termos da taxa anual, incrementouse a un ritmo do 1,5\% anual. 0 acrecentamento produciuse a un ritmo exponencial na poboación estranxeira: o 23,5\%, fronte ao 0,4\% da poboación autóctona. Deste xeito, pasamos de 637.085 estranxeiros no ano 1998 a máis de 5 millóns no 2008. A partir dese ano, produciuse un descenso notable de estranxeiros chegados a España e a cifra foi en descenso de forma paulatina ata o ano 2010, onde pasou a ter fluxo positivo.

A maior diminución de inmigración de todos os países da Organización para o Desenvolvemento e o Crecemento Económico (OCDE ou OECD polas súas siglas en inglés) tivo lugar entre os anos 2007 e 2013 como consecuencia da crise. Con todo, segundo o informe International Migration Outlook 2015 (OECD, 2015), no ano 2014, grazas á mellora das condicións e do mercado de traballo, esta tendencia deu un xiro e a inmigración comezou a incrementarse, situándose España por detrás do Reino Unido e de Alemaña (OECD, 2015).

Na Unión Europea, os cidadáns estranxeiros representaban o 1 de xaneiro de 2017, segundo os datos de Eurostat, o 7,5\% dos suxeitos que residen nos Estados membros, situándose no caso de España no 11,26\% (5,237 millóns, segundo datos do Observatorio Permanente da Inmigración [OPI], para unha poboación total de 46,529 millóns). Estas cifras refírense aos estranxeiros que aínda non se nacionalizaron, pois hai cidadáns nacionalizados de orixe estranxeira que non se inclúen nesa porcentaxe. Tamén inclúe residentes da terceira idade que non realizan actividades laborais e que reciben pensións dos seus países de orixe. Estímase en preto de 230 mil o número de xubilados dese grupo, polo que os estranxeiros en idade laboral ou menores de idade serían aproximadamente 5,007 millóns.

O Instituto Nacional de Estadística (INE) indica que o número de nados no estranxeiro residentes en España era de 6,180 millóns no ano 2017, dos cales 2,076 tiñan xa nacionalidade española (algúns de nacemento por ser fillos de españois e outros por adquisición da nacionalidade) e 4,103 tiñan nacionalidade estranxeira. Se descontamos da cifra de 6,18 millóns aos fillos de españois nados no estranxeiro e lle sumamos os fillos de estranxeiros nados en España, teríamos unha cifra superior a 6,18 millóns de persoas descendentes de estranxeiros que residen en España, o que representa algo máis do $13 \%$ da poboación española.

Os últimos datos do OPI indican que os estranxeiros con certificado de rexistro ou tarxeta de residencia en vigor se situaban en xuño de 2018 en 5.331.774, concretamente 3.195 .942 persoas suxeitas ao Réxime de Libre Circulación UE (59,9\%) e 2.135.832 ao Réxime Xeral (40,1\%). En comparación con 2017, cuxo número de estranxeiros residentes en España se situaba en 5.237.710, evidénciase un aumento de $94.064(1,8 \%)$ persoas repartidas en 71.352 individuos no Réxime de Libre Circulación UE e de 22.712 no Réxime Xeral, cun 2,3\% e cun 1,1\% respectivamente. Do total da poboación estranxeira, o 65,9\% concéntrase en Cataluña, na Comunidade de Madrid, en Andalucía e na Comunidade Valenciana. Na primeira residen 565.905 estranxeiros e na segunda e na terceira 511.254 e 497.544 , respectivamente. A última acolle 476.758 estranxeiros no Réxime de Libre Circulación UE (Táboa 1).

O feito de que a cifra do INE para o ano 2017 indique un número de residentes de nacionalidade estranxeira claramente menor que a cifra do OPI poderíase explicar porque o INE só inclúe residentes en 
situación legal, mentres que o OPI inclúe tamén os que están en situación irregular. A diferenza (entre 5,237 e 4,103 millóns de persoas) é de 1,276 millóns de cidadáns estranxeiros residentes en situación irregular ou non computables por outros motivos.

Táboa 1. Estranxeiros con certificado de rexistro ou tarxeta de residencia en vigor a 30/06/2018 segundo réxime xurídico e comunidade autónoma de residencia

\begin{tabular}{lcc}
\hline & \multicolumn{2}{c}{$30-06-2018$} \\
\cline { 2 - 3 } \multicolumn{1}{c}{ CC.AA. } & R. Libre Circulación UE & R. Xeral \\
\cline { 2 - 3 } & 3.195 .942 & 2.135 .832 \\
\hline Cataluña & 565.905 & 606.393 \\
Madrid & 511.254 & 352.152 \\
Andalucía & 497.544 & 263.309 \\
C. Valenciana & 476.758 & 235.953 \\
Canarias & 227.803 & 70.792 \\
Baleares & 168.498 & 72.303 \\
Rexión de Murcia & 72.512 & 150.024 \\
Castela-A Mancha & 139.500 & 69.641 \\
Aragón & 123.392 & 62.832 \\
Castela e León & 127.600 & 49.816 \\
País Vasco & 65.326 & 68.065 \\
Galicia & 65.597 & 30.160 \\
Comunidade Foral de Navarra & 35.421 & 25.111 \\
Estremadura & 32.043 & 14.969 \\
A Rioxa & 25.285 & 19.575 \\
Principado de Asturias & 29.172 & 13.330 \\
Cantabria & 23.440 & 13.327 \\
Melilla (Cidade Autónoma de) & 5.087 & 10.040 \\
Ceuta (Cidade Autónoma de) & 3.024 & 2.784 \\
\hline
\end{tabular}

Fonte: adaptado do OPI (2018, p. 3).

Polo que respecta aos estranxeiros con certificado de rexistro ou tarxeta de residencia en vigor a 30/06/2018, o informe sinala que Madrid e Barcelona son as provincias cun número máis elevado de residentes, acadando entrambas as dúas máis do 30\%. Na Figura 1 pódense observar os estranxeiros residentes por provincias, e cómpre sinalar que en 37 delas habitan menos de 100.000 estranxeiros.

Os irregulares foron 25.251, o que representa un 4,74\%. Parece que a cifra de irregulares contabilizados é inferior á cifra de estranxeiros residentes sen regularizar, tendo en conta a diferenza de máis de 1 millón de persoas entre os datos do OPI e os do INE. No ano 2016, con respecto aos inmigrantes irregulares e con base nos últimos datos do Ministerio do Interior ${ }^{1}$, que corresponden ao exercicio 2016, foron 503.653 persoas as que chegaron ao continente europeo por vía marítima e terrestre. En España o número foi de 14.558 persoas procedentes de todo o mundo.

O Ministerio do Interior indica tamén que no ano 2017 a cifra de irregulares que chegaron a España se incrementou significativamente en cotexo co 2016, ata se situar en 25.251. É máis, 2017 foi un ano para ter en conta, xa que desde que se teñen cifras, e excluíndo 2006, nunca chegaran tantos inmigrantes irregulares ao país.

Con base nos últimos datos dos que dispón o Ministerio do Interior correspondentes ao período que comprende desde o 1 de xaneiro ata o 20 de novembro de 2018, hai que sinalar que, en total, as

\footnotetext{
${ }^{1}$ Datos referidos ao último balance anual do Ministerio do Interior (2016).
} 
persoas que chegaron a España (tanto por vía marítima como por vía terrestre) foron 59.048. Como se ve na Táboa 2, esa cifra, en comparación cos xa referidos 25.786 do ano 2017, evidencia un incremento exponencial, pois dóbrase a cifra a falta aínda de pechar o ano.

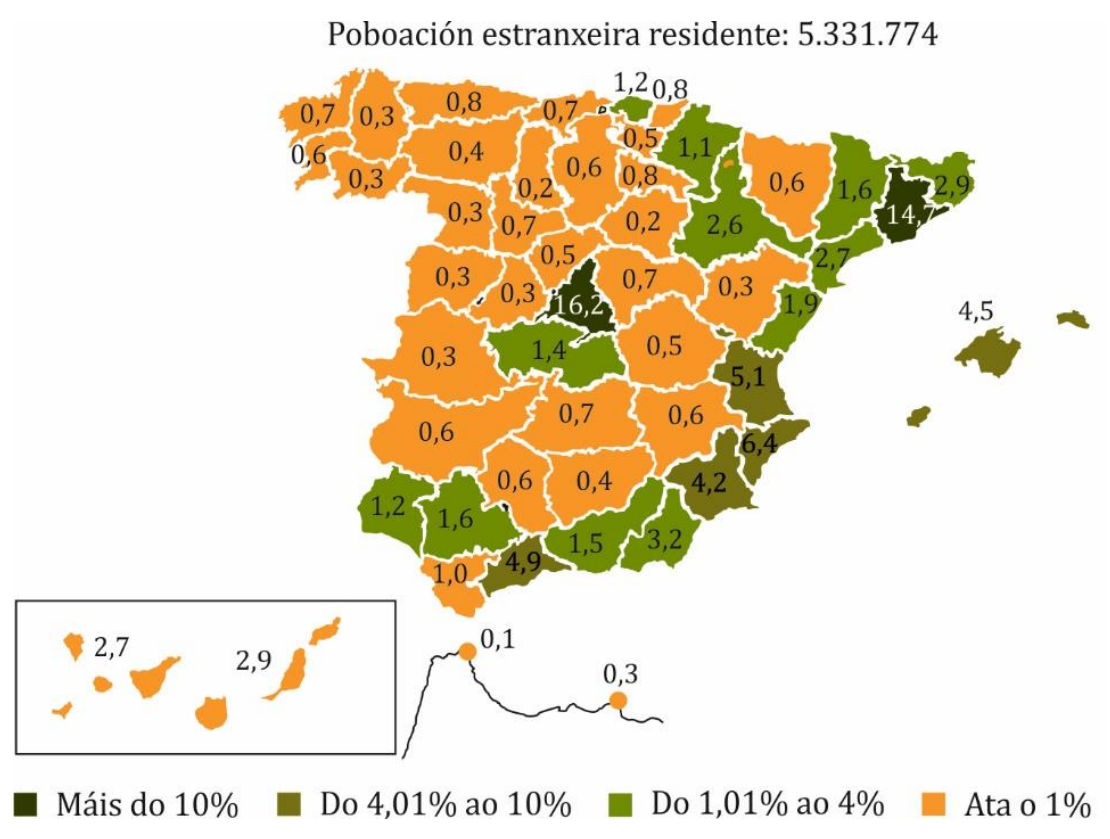

Figura 1. Mapa da distribución provincial de estranxeiros con certificado de rexistro ou tarxeta de residencia en vigor a 30/06/2018 (\%). Fonte: recuperado do OPI $(2018$, p. 3).

Táboa 2. Datos acumulados do 1 de xaneiro ao 30 de novembro e comparativa con 2017

\begin{tabular}{lcccc}
\hline & $2018^{*}$ & 2017 & Diferenza & $\%$ \\
\hline Chegada de inmigrantes * & 59.048 & 25.786 & +33.262 & $+129,0$ \\
\hline
\end{tabular}

Nota: *Por vía marítima e terrestre. Fonte: datos provisionais do Ministerio do Interior (2018).

\section{Política migratoria e cooperación internacional}

A principios do século XIX comezaron a nacer as primeiras normas. Estas regulacións non diferenciaban entre inmigración legal e irregular e, verdadeiramente, tampouco limitaban a migración en xeral, unicamente algúns tipos de persoas, por exemplo, os tolos, os que tiñan "malos costumes", os doentes, os delincuentes ou individuos moralmente considerados nalgúns países como racialmente non desexables -polacos ou xudeus- (Düvell, 2006).

Os primeiros países europeos que empezaron a aplicar as primeiras restricións á migración foron o Reino Unido e Alemaña, culpando aos/ás inmigrantes das dificultades propias da época como a fame, a pobreza, a delincuencia, a superpoboación ou o traballo clandestino. Dous feitos acontecidos logo da Primeira Guerra Mundial marcaron realmente o control efectivo da migración: o procedemento de deportación e a creación dos pasaportes (Lucassen, 2001). A representación dunha "inmigración ilegal" enraizouse co referido concepto de Estado-nación moderno que apareceu despois do mencionado con- 
flito bélico. A tendencia máis estendida no período posterior á guerra era a emigración desde o continente europeo e tamén o movemento dun enorme número de refuxiados. Italia, o Reino Unido, os Países Baixos, Portugal e España eran os principais países de orixe. O país receptor por excelencia era EE.UU., seguido de Arxentina, Brasil, Canadá, Venezuela e Sudáfrica, entre outros.

A mediados do século XX, a migración internacional volveu xurdir naquelas áreas menos desenvolvidas dos países do norte de Europa. A capacidade produtiva do continente europeo incrementouse notablemente e, en consecuencia, tamén aumentou a necesidade de man de obra das industrias en auxe, especialmente nos países que perderan moita poboación na Segunda Guerra Mundial. Así, países como Alemaña, Francia ou o Reino Unido utilizaron diferentes mecanismos, como a sinatura de pactos bilaterais dos traballadores migrantes ou os programas de traballadores temporais. Chegou unha gran cantidade de traballadores non cualificados pero, fronte á elevada demanda de man de obra, levouse a cabo unha política de inmigración con múltiples facilidades para a regulación, unha vez que atoparan un posto de traballo e, así mesmo, facilitáronse reunificacións familiares e concedéronse estadías longas. Todo iso provocou que a inmigración aumentase notablemente e que os que chegaran quedasen de forma permanente (García, 2015).

A inmigración irregular na procura de traballo comezou a ser obxecto de análise nas políticas e debates sociais na Europa dos anos sesenta. Ademais, empezou a ser considerada un problema social de moita importancia pola súa magnitude e polo seu crecente aumento, así como polos seus efectos como, entre outros, a evasión de impostos, o conflito coa sociedade de acollida, o exceso de uso dos servizos públicos e de saúde ou a visión social sobre a ingobernabilidade do fenómeno (Ortega, 2014).

Os Estados comezaron a instituír leis sobre a inmigración sumamente restritivas, ademais de paralizar a reunificación de familias e os programas de traballadores temporais. As economías mundiais estaban a ser sacudidas pola denominada crise do petróleo de mediados dos anos setenta, que marca un punto de inflexión nas políticas de admisión de moitos países europeos, que limitaron en gran medida as situacións de transitoriedade laboral. Instáurase a suspensión da incorporación de traballadores, contexto que tivo como efecto colateral o incremento da inmigración ilegal.

As consecuencias sociais durante estes anos foron evidentes na Europa occidental, pois certos sectores da sociedade reaccionaron de forma negativa e mesmo enfrontándose á inmigración. Isto sucedeu cando os traballadores "temporais" empezaron a vivir nos seus territorios, a traer os seus familiares e comezaron a utilizar os servizos sociais nun período económico complicado, cun elevado paro e cunha diminución dos servizos sociais.

As institucións europeas, durante os anos oitenta e principios dos noventa, puxeron o foco de interese naqueles suxeitos solicitantes de asilo e na migración ilegal e de refuxiados, converténdose estes fenómenos no tema central das políticas migratorias dos Estados membros. A década dos anos noventa tamén foi prolífera en controlar esta inmigración mediante a esixencia de visas, controis de fronteiras moi estritos, revisións polo miúdo de documentos de identidade, condenas severas por tráfico de persoas ou por contrabando, renovadas políticas de asilo ou limitación de prestacións e servizos sociais aos ilegais (Düvell, 2006).

0 aumento dos fluxos migratorios foi un problema crecente para gobernos, organismos internacionais e intergobernamentais e para a sociedade en xeral, xa que estes fluxos trouxeron consigo consecuencias vinculadas ás relacións sociais e políticas nos países de orixe e receptores da inmigración. Nos países do sur de Europa, as secuelas da inmigración débense tratar tendo presente a política migratoria europea. España non foi consciente da importancia da inmigración ata a promulgación en 1985 da Lei de estranxeiría, feito que se produciu un ano antes do ingreso de España na UE. Ata ese momento non houbera unha necesidade perentoria de regular o fenómeno inmigratorio dun modo preciso. Porén, como apuntan varios autores, esa Lei evidencia unha aproximación ao fenómeno onde prevalece a vocación de establecemento temporal, a limitación de dereitos e deberes do inmigrante, así como a fraxilidade do seu estatuto xurídico (Aja, 2006; Arango, 2000; López, 2007; Sánchez, 2011).

No imaxinario social español, a figura do inmigrante "ilegal", "indocumentado" ou "irregular" xorde coa referida Lei (Carrillo e Delgado, 1998). Posteriormente, aprobouse a Lei orgánica 4/2000, de 11 de xaneiro, sobre dereitos e liberdades dos estranxeiros en España e a súa integración social (LOEX), que 
foi modificada polas seguintes leis orgánicas: LO 8/2000, de 22 de decembro; LO 11/2003, de 29 de setembro; LO 2/2009, de 11 de decembro; e LO 10/2011, de 27 de xullo (ademais de sucesivos regulamentos: RD 864/2001, RD 2393/2004 e RD 557/2011).

Queremos sinalar, a modo de reflexión, que un dos obxectivos primordiais era poñerlle fin á inmigración ilegal, o que non se conseguiu, e isto é un dos maiores atrancos e o máis perceptible entre os ditos cometidos declarados nas políticas migratorias española e europea.

Para poder levar a cabo unha boa política migratoria é preciso que a política e a lexislación se apoien mutuamente en estruturas axeitadas para a súa instauración, así como acadar condicións socioeconómicas suficientes para iso.

Polo que respecta á cooperación internacional, hai que sinalar que, ademais de acoller os inmigrantes que se adaptan á capacidade do país, España e Europa poden desenvolver políticas importantes de apoio á paz e ao desenvolvemento nos países de orixe, así como protexer os refuxiados en países próximos aos seus países de orixe.

Guisán, Aguayo e Expósito (2015) presentan un interesante estudo das vías de cooperación internacional. España destaca pola súa achega ao desenvolvemento a través das rendas transferidas como remesas que os inmigrantes envían aos seus países (máis de 17.000 millóns no ano 2017). Ademais das remesas dos emigrantes, hai outras formas importantes de cooperación internacional, como se indica no mencionado estudo: investimento directo, axuda privada e non oficial, axuda oficial ao desenvolvemento, comercio exterior de bens, ingresos por turismo... Esas autoras conclúen que para mellorar a calidade de vida nos países de orixe dos emigrantes é esencial aumentar o investimento e o gasto en educación, xa que, como se conclúe de varios estudos empíricos, se demostrou que o aumento do gasto educativo é esencial para o incremento da renda por habitante, o acceso axeitado á atención sanitaria, o aumento da esperanza de vida, a erradicación da pobreza e a mellora da organización social.

\section{Causas e efectos da inmigración regular e irregular}

\subsection{Causas}

Polo que respecta ás causas, as migracións poden estar provocadas por diversos fenómenos políticos, económicos ou demográficos, por exemplo. Hai factores de expulsión e factores de atracción.

En relación cos primeiros -os factores de expulsión-, podemos sinalar que se deben polo xeral aos conflitos internos, rexionais e internacionais. A falta de liberdades e de dereitos políticos e a corrupción endémica en moitos países son causas que levan ás persoas a se iren na procura dunha maior liberdade, así como a guerra e os conflitos armados, entre outros.

Con respecto aos factores económicos de expulsión, podemos destacar os derivados da fame e das grandes diverxencias de renda. A inmigración é a secuela de varios factores, en certos casos moi complexos, e que afectan de modo moi desigual en cada caso; porén, nunha porcentaxe elevada é a consecuencia fundamental "de violaciones de los derechos sociales, económicos y políticos de hombres, mujeres y niños que emigran supuestamente hacia la paz y hacia el bienestar político, socioeconómico y humano" (Guillén, 2011, pp. 13-15).

Entre os factores de atracción podemos destacar o incremento da demanda (demanda de traballadores ou oferta de postos de traballo) por parte dos países desenvolvidos, particularmente no sector servizos, e as asimetrías de crédito ou a oportunidade de crecer laboralmente.

Entre os elementos demográficos pódese sinalar que a superpoboación inflúe para o país de orixe e, pola súa banda, para o país receptor faríao o avellentamento e a baixa taxa de natalidade (Gómez Walteros, 2010).

Tamén existen factores culturais, educativos, tecnolóxicos ou científicos. Entre os países economicamente desenvolvidos e os que están en vías de desenvolvemento existe unha enorme fenda científica e tecnolóxica que, sen dúbida, é un motivo que beneficia este tipo de desprazamento para o desempeño laboral, a formación ou a cualificación. 


\subsection{Efectos}

En relación cos efectos, cómpre sinalar que o asunto da inmigración, e especialmente o da inmigración ilegal, é un tema tanto social como económico. Para comezar, ambos os dous tipos de inmigración determinan a convivencia de heteroxéneas culturas e, economicamente, entre outros factores, está o aumento de man de obra en países que padecen problemas de desemprego interno e, ademais, que a súa capacidade de absorber nova man de obra é limitada e, polo tanto, aumentan algunhas bolsas de pobreza.

A inmigración ten unha natureza basicamente económica e induce os seus efectos nesa área. Tamén incide no contexto sociocultural, xa que a sociedade receptora pode ter unha inquietude con respecto á conservación da identidade cultural ou á capacidade de xestionar o proceso multicultural que deriva da inmigración. Como xa se sinalou, os inmigrantes produtivos e que se integran poden levar a cabo unha grande achega ao progreso económico e, ademais, sen custo para a poboación do país de acollida. Porén, as consecuencias positivas tamén poden desaparecer se os inmigrantes non se adaptan e non posúen a preparación necesaria (Borjas, 1994). Hai que considerar que os efectos da migración dependen de moitos factores e non unicamente do capital humano que brindan; por exemplo, son tamén factores que estimar a integración, o impacto no capital público ou as particularidades persoais, por exemplo. A inmigración pode ser prexudicial ou frutuosa dependendo do lugar e do tempo.

\subsection{Inmigración regular e inmigración irregular}

Polo que respecta á inmigración regular, hai que sinalar que a inmigración legal axustada ás posibilidades do país de acollida, entendida como un elemento de desenvolvemento e avance, é a inmigración que se axeita á capacidade de acollida da sociedade e ás posibilidades do mercado de traballo, de modo que o seu labor cobre a falta ou a diminución de man de obra no país de acollida. Cando un país acepta inmigración legal máis alá da súa capacidade de emprego, só co obxectivo de diminuír os salarios nalgúns sectores, ocasiona problemas de desemprego da poboación do país e mesmo dos inmigrantes xa establecidos. Iso ten un custo para o sector público en subsidios de desemprego e noutros gastos para atender tanto aos españois como aos estranxeiros en situación de desemprego.

A inmigración regular excesiva pode causar problemas económicos, pero normalmente non causa problemas sociais se está debidamente regulada.

Pola súa banda, a inmigración irregular é na que cae a carga negativa relacionada coa delincuencia, a marxinación, a explotación ou o tráfico de persoas por mafias. A inmigración irregular non é considerada conveniente na maioría dos países, xa que en xeral provoca moitos máis problemas que a inmigración regular, non só de tipo económico, cando supera a capacidade de acollida, senón tamén de tipo social por falta de regulación. A cooperación europea ao desenvolvemento debería abordar a axuda, nos seus países de orixe ou na súa contorna, aos cidadáns de países que sofren numerosas carencias, tratando de apoiar a inmigración regular, dentro das capacidades de cada país, e evitar os problemas da inmigración irregular. Unha vez decidido o número de inmigrantes que cada país pode integrar, deben de fortalecerse as canles de acceso e o control para que a inmigración sexa legal.

\subsection{Inmigración e mercado de traballo}

Un asunto de moita preocupación para a poboación do país receptor é coñecer as incidencias da inmigración no mercado de traballo. 0 modelo migratorio de España posúe un factor principal: a súa natureza laboral. Entre os albores do século XXI e ata o ano 2008, os inmigrantes ocuparon traballos que os españois rexeitaban. Para Amuedo-Dorantes e De la Rica (2011), os inmigrantes posúen particularidades diferentes dos autóctonos e, en consecuencia, non son substitutivos no mercado laboral senón que se concentran xeralmente en traballos máis manuais, mentres que os españois o fan naque- 
les cun grao máis elevado de sofisticación, de especialización e con mellores retribucións. É dicir, que a poboación inmigrante constituíu unha man de obra complementaria á de aquí.

Os efectos da recesión económica que viviu España son diferentes para os españois que para os inmigrantes. Os inmigrantes amoreáronse, como xa se sinalou, en sectores económicos como o da construción, que foron golpeados con máis dureza pola recesión. A perda do traballo trouxo consigo varios problemas agregados a este colectivo. 0 reagrupamento familiar, coa política inmigratoria actual, tamén é inviable se non se ten traballo; é preciso ter unha vivenda e un nivel de ingresos mínimos para que os/as inmigrantes o poidan solicitar. Un factor característico da inmigración eran as remesas de diñeiro que enviaban aos seus países natais, algo que coa perda de traballo diminuíu de xeito significativo. Do mesmo xeito que os españois, o problema da vivenda fai que se vexan desamparados fronte aos desafiuzamentos.

No contexto económico actual que vive o noso país, esta situación deixa os inmigrantes regulares nunha situación de incerteza debido a que se perden o seu traballo poderán ter acceso ás prestacións por desemprego e renovar o seu permiso, malia que, cando remate a prestación, se agregarán aos irregulares, xa que a lexislación neste punto non ten mecanismos para que estes suxeitos poidan seguir residindo de forma regular. Ademais, os que non teñen dereito á prestación por desemprego, ben porque a esgotaron ou ben porque non cotizaron o suficiente, veranse abocados directamente á irregularidade. Tanto para os cidadáns irregulares como para a sociedade de acollida, a situación de irregularidade pode supoñer consecuencias negativas.

Como se fará referencia máis adiante, créase unha economía somerxida por non poder acceder a un emprego, o que provoca en moitas ocasións que sexan vítimas de soldos irrisorios ou que teñan que facer xornadas laborais exhaustivas. Isto provoca que o Estado deixa de percibir ingresos pola súa actividade económica. Así mesmo, dificúltase e restrínxese o acceso aos servizos sociais, e tampouco teñen a posibilidade de poder obter a renda mínima de inserción ou outras axudas (Manzanares e Riquelme, 2017). Esta situación implica, ademais, que a súa integración na sociedade española se complique moito, xa que poden padecer discriminación.

A persoa que pasa a ser ilegal ve minguados os seus ingresos, a súa liberdade de circulación, o seu dereito laboral ou o acceso a unha vivenda. Á parte da traxedia humana que implica estar nunha situación irregular, o incremento desa poboación unicamente provoca contextos de maior explotación laboral, que sexan estigmatizados socialmente e a precariedade dun colectivo onde a forma de vida se atopa na economía informal. Por desgraza, os recursos aos que poden acceder estas persoas son moi escasos e practicamente só lles queda recorrer ás axudas do terceiro sector. A problemática de acceder aos servizos sociais é o motivo polo que tanto as ONG como outras organizacións como Cáritas ou a Cruz Vermella interveñen neste colectivo. Normalmente, os servizos que prestan son de intervención social, como de acollida, asesoramento xurídico e información, e derivación a psicólogos, avogados ou a formación (alfabetización, clases de castelán, cursos, obradoiros...).

\section{Inmigración ilegal por vía marítima}

Por último, cómpre facer unha referencia a este tipo de inmigración pola súa fonda repercusión a nivel social e porque é unha das grandes preocupacións da sociedade española. Desde hai uns anos, persoas en pateiras e caiucos están a arriscar a súa vida desde África, un fenómeno que precisa dunha inmediata reacción. Malia que no territorio español a canle de entrada principal de clandestinos foi por avión ou polas fronteiras terrestres, e non por vía marítima, a relevancia desta terrible realidade radica en elementos cualitativos. Para empezar, é un dos tipos de migración máis perigosos e implica múltiples contextos de emerxencia humanitaria, que son verdadeiros dramas polas mortes que supoñen. Estes fenómenos están relacionados en maior ou menor medida coas redes do crime organizado que, sen ningún tipo de escrúpulos, explotan os inmigrantes sen papeis ofrecéndolles o edén europeo a cambio dos seus escasos aforros nunha viaxe terrible en todo tipo de embarcacións totalmente inapropiadas. 
Este tipo de inmigración foi crecendo en interese na UE e nos Estados membros nos últimos anos, desde que se sucederon crises migratorias no mar que tiveron como consecuencia a agregación da loita contra a inmigración irregular por vía marítima nas axendas políticas, feito ao que contribuí ron en gran medida as denuncias e presións de diversas $\mathrm{ONG}$, as dinámicas electorais ou a opinión pública.

Porén, hai que sinalar que esta atención custou bastante tempo e implicacións, xa que o tráfico humano por vía marítima é, como se xa se sinalou, menor cuantitativamente, e tamén porque o problema está basicamente limitado a Italia, España e Grecia. Grazas ao abraio da sociedade ante este fenómeno e á súa difusión nos medios de comunicación, xa se fala con claridade dese drama. A continuación, expóñense datos recentes deste fenómeno e dos países referidos segundo o informe Mediterranean Migrant Arrivals, elaborado no ano 2007 pola International Organization for Migration (OIM).

A Táboa 3 mostra que un total de 46.449 persoas entre migrantes e refuxiados chegaron a Europa por vía marítima entre xaneiro e xullo de 2018. Se esta cifra se cotexa coa do mesmo período de 2017, que foi de 101.213, vese un descenso substantivo. Non obstante, como refire tamén o dito informe, a travesía volveuse moito máis complicada e perigosa, e iso vese reflectido na maior proporción de persoas falecidas no ano 2018, tamén en comparación co ano anterior.

A táboa 4 amosa o número total de chegadas por vía marítima en Italia, Grecia e España para o período 2014-2017.

Táboa 3. Total chegadas polo Mediterráneo, 2017-2018

\begin{tabular}{|c|c|c|c|c|c|}
\hline \multirow[b]{2}{*}{$\begin{array}{l}\text { Países de } \\
\text { chegada }\end{array}$} & \multicolumn{2}{|c|}{$\begin{array}{l}\text { Entre o } 1 \text { de xaneiro e } \\
\text { o } 4 \text { de xullo de } 2018\end{array}$} & \multirow{2}{*}{$\begin{array}{c}\text { Entre o } 1 \text { e o } 4 \\
\text { de xullo de } \\
2018\end{array}$} & \multicolumn{2}{|c|}{$\begin{array}{l}\text { Entre o } 1 \text { de xaneiro e } \\
\text { o } 4 \text { de xullo de } 2017\end{array}$} \\
\hline & Chegadas & Mortes & & Chegadas & Mortes \\
\hline Italia & 16.707 & $\begin{array}{c}1.074 \text { (Ruta } \\
\text { central Med*) }\end{array}$ & 130 & 85.137 & $\begin{array}{c}2.185 \text { (Ruta } \\
\text { central Med) }\end{array}$ \\
\hline Malta & 243 & & 9 & $\mathrm{~N} / \mathrm{A}$ & \\
\hline Grecia & 13.826 & $\begin{array}{c}45 \text { (Ruta oriental } \\
\text { Med) }\end{array}$ & 360 & 9,290 & $\begin{array}{c}37 \text { (Ruta oriental } \\
\text { Med) }\end{array}$ \\
\hline Chipre & 47 & & 0 & 237 & \\
\hline España & 15.626 & $\begin{array}{c}293 \text { (Ruta oriental } \\
\text { Med) }\end{array}$ & 550 & $\begin{array}{c}6.513(\mathrm{a} \\
\text { partir do } 30 \\
\text { de xuño) }\end{array}$ & $\begin{array}{c}118 \text { (Ruta } \\
\text { oriental Med) }\end{array}$ \\
\hline TOTAL & 46.449 & 1.412 & 1.049 & 101.213 & 2.340 \\
\hline
\end{tabular}

Fonte: adaptación de Mediterranean Migrant Arrivals (OIM, 2018).

Táboa 4. Chegadas totais polo mar: Italia, Grecia e España

\begin{tabular}{lcccc}
\hline Países & 2014 & 2015 & 2016 & 2017 \\
\hline Italia & 170.100 & 153.842 & 181.436 & 119.369 \\
Grecia & 34.442 & 835.650 & 173.614 & 29.595 \\
España & $\mathrm{N} / \mathrm{A}$ & 5.309 & 8.162 & 22.108 \\
\hline
\end{tabular}

Fonte: adaptación de OIM (2018). 
A continuación, na táboa 5 preséntase a evolución experimentada en España en canto ás exposicións mensuais de chegadas por vía marítima para o período comprendido entre os anos 2015 e 2018.

Táboa 5. España: chegadas de inmigrantes ao mes polo mar entre os anos 2015 e 2018

\begin{tabular}{lcccc}
\hline Meses & 2015 & 2016 & 2017 & 2018 \\
\hline Xaneiro & 264 & 492 & 1.049 & 1.400 \\
Febreiro & 44 & 222 & 535 & 1.102 \\
Marzo & 280 & 351 & 842 & 867 \\
Abril & 243 & 451 & 900 & 1.258 \\
Maio & 512 & 575 & 835 & 3.523 \\
Xuño & 414 & 715 & 2.352 & 6.926 \\
Xullo & 409 & 458 & 2.164 & 550 \\
Agosto & 417 & 934 & 2.203 & $/$ \\
Setembro & 621 & 1.248 & 1.486 & $/$ \\
Outubro & 1.059 & 1.110 & 3.616 & $/$ \\
Novembro & 557 & 854 & 4.061 & $/$ \\
Decembro & 492 & 752 & 2.065 & $/$ \\
TOTAL & 5.309 & 8.162 & 22.108 & 15.626 \\
\hline
\end{tabular}

Fonte: adaptación de OIM (2018).

\section{Conclusións}

Dos datos analizados podemos extraer que en España, onde se obtiveron cotas moi elevadas de inmigración equiparables coas doutros países da UE, se orixinou un proceso migratorio moi intenso e rápido. Isto levou aos españois, como sociedade receptora de inmigrantes, a unha serie de cambios sociais que, sen dúbida, implicaron múltiples desafíos referidos á integración social na diversidade, á articulación da convivencia ou á garantía de dereitos básicos.

É necesario regular a inmigración o máximo posible para que sexa legal e con responsabilidade social, é dicir, se un país admite un determinado número de inmigrantes debe comprometerse a proporcionarlles unhas condicións de vida dignas, sen menoscabo da calidade de vida dos cidadáns que xa residían no país.

En España, a inmigración é un fenómeno relativamente novo, e máis a inmigración irregular, unha peza deste fenómeno migratorio. Por isto, teranse que levar a cabo mecanismos e programas que a canalicen cara a unha dirección positiva. Analizar e tratar esta realidade desde unha perspectiva máis sociolóxica e menos numérica podería ser un primeiro paso para tal labor, así como fomentar a cooperación internacional ao desenvolvemento axudando a buscar solucións para que se protexan os dereitos humanos, o desenvolvemento económico e a calidade de vida en todos os países do mundo. A cooperación internacional ao desenvolvemento debería ser unha prioridade na política europea.

\section{Bibliografía}

Aja, E. (2006). La evolución de la normativa sobre inmigración. En E. Aja e J. Arango (Eds.), Veinte años de inmigración en España. Perspectiva jurídica y sociológica (pp. 17-44). Barcelona: Fundación CIDOB.

Amuedo-Dorantes, C., e Rica, S. de la. (2011). Complements or substitutes? Task specialization by gender and nativity in Spain. Labour Economics, 18(5), 697-707. DOI: https://doi.org/10.1016/j.labeco.2011.02.002 
Arango, J. (2000). Becoming a country of immigration at the end of the twentieth century: The case of Spain. En R. King, G. Lazaridis e Ch. Tsardanidis (Eds.), Eldorado or fortress? Migration in Southern Europe (pp. 253256). London, England: Macmillan. DOI: https://doi.org/10.1057/9780333982525 12

Arvin, M., e Lew, B. (Eds.). (2015): Handbook on the economics of foreign aid. Cheltenham, England: Edward Elgar. Recuperado de

https://books.google.es/books/about/Handbook on the Economics of Foreign Aid.html?id=IUyrCgAAQBAI \&printsec=frontcover\&source $=\mathrm{kp}$ read button\&redir esc $=\mathrm{y} \# \mathrm{v}=0$ onepage \&q\&f=false

Borjas, G. (1994). The economics of migration. Journal of Economic Literature, XXXII, 1667-1171. Recuperado de https://sites.hks.harvard.edu/fs/gborjas/publications/journal/JEL1994.pdf

Carrasco, R., Jimeno, J. F., e Ortega, C. (2008). The effect of immigration on the labor market performance of native-born workers: Some evidence for Spain. Journal of Population Economics, 21(3), 627-648. DOI: https://doi.org/10.1007/s00148-006-0112-9

Carrillo, E., e Delgado, L. (1998). El entorno, los instrumentos y la evolución de la política de inmigración en Espa$\tilde{n} a$ (1985-1996). Madrid: Instituto Universitario Ortega y Gasset.

Castillo, J. (2011). Migraciones ambientales: huyendo de la crisis ecológica en el siglo XXI. Barcelona: Virus. Recuperado de https://www.fuhem.es/media/cdv/file/biblioteca/Boletin ECOS/33/migraciones ambientales.pdf

Düvell, F. (2006). Irregular migration: A global, historical and economic perspective. En F. Düvell (Ed.), Illegal immigration in Europe. Beyond control? (pp. 14-39). London, England: Palgrave Macmillan. https://doi.org/10.1057/9780230555020 2

Eurostat. (2018). Estadísticas de migración y población migrante. Luxembourg, Luxembourg: Eurostat.

Farré, L., González, L., e Ortega, F. (2010). Immigration, family responsibilities and the labor supply of skilled native women. INSIDE Paper, 17. Bellaterra (Barcelona): INSIDE (Insights on Immigration and Development), Institute for Economic Analysis, CSIC. Recuperado de http://www.inside.org.es/wp-content/files flutter/1268640534Inside 17.pdf

García, L. (2015). Medidas y condiciones de integración de inmigrantes: una propuesta europea difícil de articular en España. Migraciones, 38, 88-110. DOI: https://doi.org/10.14422/mig.i38.y2015.004

Giddens, A. (2007). Europa en la era global. Barcelona: Paidós.

Gómez Walteros, J. A. (2010). La migración internacional: teorías y enfoques, una mirada actual. Semestre Económico, 13(26), 81-99. Recuperado de https://dialnet.unirioja.es/servlet/articulo?codigo=3236897

González Enríquez, C. (2009). Spain: The cheap model. Irregularity and regularisation as immigration management policies. European Journal of Migration and Law, 11(2), 139-157. DOI: https://doi.org/10.1163/157181609x440004

González Enríquez, C. (2013). Circularity in a restrictive framework: Mobility between Morocco and Spain. En A. Triandafyllidou (Ed.), Circular migration between Europe and its neighbourhood: Choice or necessity. Oxford, England: OUP. DOI: https://doi.org/10.1093/acprof:oso/9780199674510.003.0006

González-Ferrer, A. (2013). Propuestas para vincular las políticas de migración y empleo. En Fundación Internacional y para Iberoamérica de Administración y Políticas Públicas (Ed.), Retorno y reintegración de los migrantes latinoamericanos en Europa (pp. 53-89). Madrid. Recuperado de http://digital.csic.es/bitstream/10261/93169/1/5390\%20Manual Propuestas\%20Vincular\%20Politicas\%20Migracion\%20y\%20Empleo 53 90.pdf

González-Ferrer, A. (2014). La inmigración por motivos familiares durante la crisis. En J. Arango, D. Moya e J. Oliver (Dirs.): Inmigración y emigración. Mitos y realidades. Anuario de la Inmigración en España 2013. Barcelona: CIDOB. Recuperado de https://www.raco.cat/index.php/AnuarioCIDOBInmigracion/article/viewFile/288375/376477

Guillén, M. (2011). Análisis de la migración irregular África-Canarias. Miradas en Movimiento, 5, 4-26. Recuperado de https://dialnet.unirioja.es/servlet/articulo? codigo $=4422459$

Guisán, M. C. (2017). Manufacturing and economic development in the world for 2000-2015: Main features and challenges. Revista Galega de Economía, 26(3), 73-88. Recuperado de http://www.usc.es/revistas/index.php/rge/article/view/4482

Guisán, M. C., Aguayo, E., e Expósito, P. (2015). MDGs and international cooperation: An analysis of private and public aid and the role of education. En B. M. Arvin e B. Lew (Ed.), Handbook on the Economics of Foreign Aid, chapter 6 (pp. 82-89). Chentelham, England: Edward Elgar. https://doi.org/10.4337/9781783474592.00013

Hatton, T. J., e Williamson, J. G. (2001). Demographic and economic pressure on emigration out of Africa. NBER Working Paper Series, 8124. Cambridge, MA: National Bureau of Economic Research.

DOI: https://doi.org/10.3386/w8124 
Herrarte, A., Medina, E., e Vicéns, J. (2007). Cambios en la situación laboral de la población española ante el incremento de la inmigración. Ekonomiaz, Revista Vasca de Economía, 66, 330-349. Recuperado de https://dialnet.unirioja.es/servlet/articulo?codigo $=3117159$

INE. (2012). Proyecciones de población 2012. Madrid: INE. Recuperado de http://www.ine.es/prensa/np744.pdf

IOM. (2007). Nota para las deliberaciones: la migración y el medio ambiente. (MC/INF/288). 94a ed. GranSaconnex, Geneva, Switzerland: IOM. Recuperado de http://governingbodies.iom.int/system/files/jahia/webdav/shared/shared/mainsite/about iom/es/council 194/MC INF 288.pdf

Ley Orgánica 7/1985, de 1 de julio, sobre derechos y libertades de los extranjeros en España. Boletín Oficial del Estado, №. 158, de 3 de julio de 1985, 20824-20829. Madrid: Jefatura del Estado Recuperado de https://www.boe.es/eli/es/lo/1985/07/01/7

Ley Orgánica 4/2000, de 11 de enero, sobre derechos y libertades de los extranjeros en España y su integración social. Boletín Oficial del Estado, №. 10, de 12 de enero de 2000, 1139-1150. Madrid: Jefatura del Estado. Recuperado de https://www.boe.es/eli/es/lo/2000/01/11/4

Ley Orgánica 8/2000, de 22 de diciembre, de reforma de la Ley Orgánica 4/2000, de 11 de enero, sobre derechos y libertades de los extranjeros en España y su integración social. Boletín Oficial del Estado, №. 307, de 23 de diciembre de 2000, 45508-45522. Madrid: Jefatura del Estado Recuperado de https://www.boe.es/eli/es/lo/2000/12/22/8

Ley Orgánica 11/2003, de 29 de septiembre, de medidas concretas en materia de seguridad ciudadana, violencia doméstica e integración social de los extranjeros. Boletín Oficial del Estado, №. 234, de 30 de septiembre de 2003, 35398-35404. Madrid: Jefatura del Estado Recuperado de https://www.boe.es/eli/es/lo/2003/09/29/11

Ley Orgánica 2/2009, de 11 de diciembre, de reforma de la Ley Orgánica 4/2000, de 11 de enero, sobre derechos y libertades de los extranjeros en España y su integración social. Boletín Oficial del Estado, №. 299, de 11 de diciembre de 2009, 104986-105031. Madrid: Jefatura del Estado Recuperado de https://www.boe.es/eli/es/lo/2009/12/11/2

Ley Orgánica 10/2011, de 27 de julio, de modificación de los artículos 31 bis y 59 bis de la Ley Orgánica 4/2000, de 11 de enero, sobre derechos y libertades de los extranjeros en España y su integración social. Boletín Oficial del Estado, №. 180, de 28 de julio de 2011, 85346-85349. Madrid: Jefatura del Estado Recuperado de https://www.boe.es/eli/es/lo/2011/07/27/10

López, A. M. (2007). La política española de inmigración en las dos últimas décadas: del asombro migratorio a la política en frontera y la integración. En Inmigración en Canarias: contexto, tendencias y retos (pp. 23-38). Santa Cruz de Tenerife: Fundación Pedro García Cabrera. Recuperado de https://digital.csic.es/handle/10261/11920

Lucassen, L. (2001). A many-headed monster: The evolution of the passport system in the Netherlands and Germany in the long nineteenth century. En J. Caplan e J. Torpey (Ed.), Documenting individual identity: The development of state practices in the modern world (pp. 235-255). Princeton, NJ: Princeton University Press. DOI: https://doi.org/10.2307/i.ctv301fxj.17

Manzanares Gutiérrez, A., e Riquelme Perea, P. (2017). Análisis espacial del desempleo en los mercados locales de trabajo españoles. Revista Galega de Economía, 26(2), 29-47. Recuperado de http://www.usc.es/econo/RGE/Vol26/rge2623.pdf

Mejías, F. (2008). El reto de la inmigración para las sociedades del bienestar. Revista de Estudios Jurídicos, 8, 233$-239$.

Ministerio del Interior. (2016). Inmigración irregular. Balance de la lucha contra la inmigración irregular. Madrid: Ministerio del Interior. Recuperado de http://www.interior.gob.es/documents/10180/3066430/Balance+2015+de+la+lucha+contra+la+inmigraci \%C3\%B3n+irregular.pdf/d67e7d4b-1cb9-4b1d-94a0-9a9ca1028f3d

Ministerio del Interior. (2017). Datos e información estadística. Madrid: Ministerio del Interior. Recuperado de http://www.interior.gob.es/documents/642317/1201562/Asilo en cifras_2017_126150899.pdf/aa9874402d98-4c7b-947c-42fd223d0a84

Ministerio del Interior. (2018). Balances e informes 2018. Madrid: Ministerio del Interior. Recuperado de http://www.interior.gob.es/ca/prensa/balances-e-informes/2018

Ministerio de Trabajo, Migraciones y Seguridad Social. (2018). Extranjeros residentes en España a 30 de junio de 2018. Principales resultados. Madrid: Ministerio de Trabajo, Migraciones y Seguridad Social. Recuperado de http://extranjeros.mitramiss.gob.es/es/Estadisticas/operaciones/concertificado/201806/Residentes Principales Resultados 30062018.pdf 
OECD. (2014): International migration outlook. Paris, France: OECD. DOI: https://doi.org/10.1787/migr outlook-2014-en

OECD. (2015): International migration outlook. Paris, France: OECD. DOI: https://doi.org/10.1787/migr outlook-2015-en

OECD. (2018): International migration outlook. Paris, France: OECD. DOI: https://doi.org/10.1787/migr outlook-2018-en

Ortega, E. (2014). La consolidación histórica de la migración irregular en Europa: leyes y políticas migratorias defectuosas. Anuario Mexicano de Derecho Internacional, XIV, 637-686. DOI: https://doi.org/10.1016/s1870-4654(14)70018-2

Pérez-Molina, J. A., e Pulido, F. (2012). Evaluación del impacto del nuevo marco legal sanitario sobre los inmigrantes en situación irregular en España: el caso de la infección por el virus de la inmunodeficiencia humana. Enfermedades Infecciosas y Microbiología Clínica, 30(8), 472-478. https://doi.org/10.1016/j.eimc.2012.07.004

Real Decreto 864/2001, de 20 de julio, por el que se aprueba el Reglamento de ejecución de la Ley Orgánica 4/2000, de 11 de enero, sobre derechos y libertades de los extranjeros en España y su integración social, reformada por Ley Orgánica 8/2000, de 22 de diciembre. [Disposición derogada]. Boletín Oficial del Estado, № 174, de 21 de julio de 2001, 26552-26603. Madrid: Ministerio de la Presidencia. Recuperado de https://www.boe.es/eli/es/rd/2001/07/20/864

Real Decreto 2393/2004, de 30 de diciembre, por el que se aprueba el Reglamento de la Ley Orgánica 4/2000, de 11 de enero, sobre derechos y libertades de los extranjeros en España y su integración social. [Disposición derogada]. Boletín Oficial del Estado, №. 6, de 7 de enero de 2005. Madrid: Ministerio de la Presidencia. Recuperado de https://www.boe.es/eli/es/rd/2004/12/30/2393/con

Real Decreto 557/2011, de 20 de abril, por el que se aprueba el Reglamento de la Ley Orgánica 4/2000, sobre derechos y libertades de los extranjeros en España y su integración social, tras su reforma por Ley Orgánica 2/2009. Boletín Oficial del Estado, №. 103, de 30 de abril de 2011. Madrid: Ministerio de la Presidencia. Recuperado de https://www.boe.es/eli/es/rd/2011/04/20/557/con

Red Acoge. (17 de julio de 2015). Los efectos de la exclusión sanitaria en las personas inmigrantes más vulnerables. Madrid: Red Acoge. Recuperado de https://www.redacoge.org/mm/file/2015/Jur\%C3\%ADdico/Informe\%20Sanidad\%20RED_ACOGE.pdf

Red Europea de Migraciones. (2012). Glosario 2.0 sobre migración y asilo. Un instrumento para una mayor comparabilidad. $2^{a}$ ed. Luxemburgo, Luxemburgo: Oficina de Publicaciones de la Unión Europea. Recuperado de https://publications.europa.eu/es/publication-detail/-/publication/f61baaae-c95d-4655-89ce$\underline{\mathrm{c} 6 \mathrm{ac} 0 \mathrm{e} 755 \mathrm{ad} 2}$

Sánchez Alonso, B. (2011). La política migratoria en España. Un análisis de largo plazo. Revista Internacional de Sociología, 69(M1), 244-268. DOI: https://doi.org/10.3989/ris.2011.im1.393

Villanueva, J. (2013). Evolución demográfica y flujos migratorios. Informes Económicos, 39. Zaragoza: Gobierno de Aragón, Departamento de Economía y Empleo, Servicio de Estudios Económicos. 